\title{
Differentiation as a business competitiveness strategy in the brewery industry in Cameroon: an analysis of Les Brasseries du Cameroun Bamenda
}

\author{
Peter N. Shille, Peter Enow \\ The University of Bamenda \\ P.O. Box 39, Bambili, Northwest region, Republic of Cameroon
}

\begin{abstract}
This study examines differentiation as a business competitiveness strategy for improving business performance in the brewery industry the case of Les Brasseries Du Cameroun Bamenda. The case study design was employed using both qualitative and quantitative techniques to assess the hypothetical relationships stated. Questionnaire and interviews were used for data collection administered to a purposefully selected sample of 130 participants comprising of management staff at Les Brasseries Du Cameroun Bamenda as well as managers and staff at retail outlets/bars in Bamenda. Using Pearson's correlation coefficient as analytical technique, results showed that there is a strong positive relationship between product differentiation, and business performance ( $\left.\mathrm{PCC}=.804^{* *}, p<0.01\right)$, moderate positive relationship between service differentiation and business performance ( $\mathrm{PCC}=.575^{* *}$, $p<0.01$ ), and a weak positive relationship between physical differentiation and business performance $\left(\mathrm{PCC}=.264^{* *}, p<0.01\right)$. The study thus provides practical advice that management should continue to maintain and uphold product differentiation variable factors like quality and assortment while at the same step-up service differentiation activities.
\end{abstract}

Keywords: product differentiation, service differentiation, physical differentiation, business performance, brewery industry

\section{Introduction}

Technological advances in the $21^{\text {st }}$ century have resulted in global market places with high degree of competition and to survive the growing competition, enterprises are adopting competitive strategies notably differentiation (Makadok, Ross, 2013). As highlighted by (Porter, 1985) an enterprises' profitability and hence performance is determined by five forces: threat of new entrants, bargaining power of suppliers, bargaining power of buyers, rivalry among competitors and threat of new substitutes. With globalization and its challenges, these five forces are visible in the brewery market in Bamenda and thus enterprises are employing competitive strategies notably differentiation to survive and stay in the market.

In the view point of Thompson and Strickland, (2007) a business competitive strategy is basically a management plan aimed at doing something different from 
competitors with the objective of delivering unique value to customers. The brewery market in Bamenda is becoming more competitive with national drinks competing with drinks imported mostly from Nigeria. With the construction of the Bamenda Mamfe - Ekok road, business between Bamenda and Nigeria has grown rapidly. This has resulted in many Nigerian drinks being sold in Bamenda and thus competing with local production.

With growing saturation of the brewery market with varied products from different enterprises, differentiation apparently may be the key success factor. For this reason and coupled with the fact that there is no evidence of previous studies in Cameroon in this same aspect as concerns differentiation that this study was deemed necessary to focus on how differentiation is being employed as a business competitiveness tool in the brewery industry making reference to Les Brasseries Du Cameroun Bamenda.

Les Brasseries du Cameroun is one of the brewery companies in Cameroon competing in the Bamenda market with other national breweries (Source du Pays, Union Camerounaise de Brasseries and Guinness Cameroun) as well as nonCameroonian breweries. All these companies are employing different strategies to show their strength in terms of quality, pricing, cost focus and differentiation focus with the sole objective of creating and ensuring customer loyalty and retention, necessary to guarantee profitability and sustenance in the market.

Les Brasseries Du Cameroun has six units/factories for the production of beers and soft drinks (with a production capacity of 3850000 hecto litre (HL) for beer and $1980000 \mathrm{HL}$ for soft drinks). These factories are located in Douala (two factories for beer and soft drinks), Yaoundé (two factories for soft drinks), Bafoussam (one factory for beer and soft drinks) and Garoua (one factory for soft drinks).

Given that Les Brasseries Du Cameroun is the oldest brewery firm in Cameroon, the fact that there are other firms competing with it as well as products from non-national breweries competing in Bamenda market, this study isolates differrentiation and examines whether it has an effect on the performance of Les Brasseries Du Cameroun in the Bamenda market. The study excludes price base competition and thus dwells on product differentiation, service differentiation and physical differentiation as the basis for analysis.

\section{Literature review and hypotheses development of product differentiation}

Product differentiation is all about creating product value be it actual or imaginary with the aim of positioning a particular product as superior in a given market. Porter (1985) upholds this view point arguing that product differentiation is all about providing a unique product valued by customers. Similarly, Chamberlin (1965) posit that product differentiation assist an enterprise to create a quasimonopoly, as such providing the enterprise more freedom to compete and gain more market share.

Pearce and Robinson, Grant, Carpenter and Marguerite, Baraza, Thiane argue that through unique product features, higher quality products and assortment, firms are able to provide superior value to customers (Pearce, Robinson, 2005; Grant, 2010; Carpenter, Marguerite, 2006; Baraza, 2017; Thiane, 2018). By so doing, 
such firms are able to compete better and win more market share. Further, Thiane, Grant, Obitz and King assert that consumer purchase behaviour is affected by product variety, with high product variety having high potential to satisfy a wide range of heterogeneous customers and hence helping an enterprise with high product variety to secure market share (Thiane, 2018; Grant, 2010; Obitz, 2009; King, 2005).

The more interesting issue about product differentiation is the fact that it focuses on the customers with the sole objective of leading to a preference (Harris, Ogbona, 2001; Pearce, Robinson, 2005; Grant, 2010; Carpenter, Marguerite, 2006; Baraza, 2017; Thiane, 2018).

Research upholds that in homogenous product markets, market niches are created primarily through product differentiation. This study builds on this idea and thus excluded pricing strategy in its analysis. The study thus argues that through employing product different as a competitive business strategy in the brewery industry, the performance of Les Brasseries Du Cameroun Bamenda can be affected. With this study argument and based on the literal works reviewed, the hypothetical relationship was stated as follows:

Hypothesis 1. Product differentiation will have no significant effect on the business performance of Les Brasseries Du Cameroun Bamenda.

Service differentiation. Service differentiation is a linking factor through which a differentiated product can easily be conveyed to customers in a market. As noted by King (2005), Schneider and Bowen (1995) service excellence is key to meeting customer needs. Basically, service quality factors necessary in a highly competitive market like the brewery market in Bamenda may include timeliness and convenience, personal attention, reliability and dependability, as well as the degree of responsiveness to customer complaints.

Apparently, service quality contributes to overall business performance. As competition becomes intense, service quality upgrades are becoming a common phenomenon. According to Thompson and Martin (2005), service differentiation brings about high customer responsiveness which brings value to customers and hence helping an enterprise to gain competitive advantage.

Therefore, service differentiation should be focused on offering value added to customers. As Sigler (2010) studying, value-added implies that services offered have additional value to the users when compared to the services of others. Apparently, value added services are provided through institutional arrangements as well as through alliances.

This study thus examines how through service differentiation as a competitive business strategy in the brewery industry, the performance of Les Brasseries Du Cameroun Bamenda has been affected. Thus the following hypothesis is developed.

Hypothesis 2. Employing service differentiation as a business competitive tool will have no significant effect on the business performance of Les Brasseries Du Cameroun Bamenda.

Physical differentiation. Physical differentiation brings about strategic benefits that help an enterprise win competitive advantage and hence improving business performance. According to Makadok and Ross (2013), differentiation notably physical differentiation helps in positioning choices independently or collabo- 
ratively so as to maximize profits. Apparently, the strategic implication of physical differentiation attained through location, convenience and layout may significantly play on business performance as it influences customer preferences.

As noted by Lilien and Kotler (1983) physical differentiation is a key component of the positioning strategy as they argued that positioning points out a target market and the ways of gaining the segment. This is visible in the brewery industry in Bamenda as distribution outlets are strategically located to fully serve the market. Similarly, Galliers (2006) argues that physical differentiation notably through location positioning is a key business performance factor utilized by enterprises in highly competitive markets. This implies that, understanding the contributions of physical differentiation to business performance is critical for business growth and sustenance especially with growing competition and saturation of markets.

Building on these viewpoints, this study investigates how through physical differentiation as a competitive business strategy in the brewery industry, the performance of Les Brasseries Du Cameroun Bamenda has been affected. The hypothesis is thus developed as follows.

Hypothesis 3. Employing physical differentiation as a business competitive tool will have no significant effect on the business performance of Les Brasseries Du Cameroun Bamenda.

Research gap. From existing literature, much has been done as concerns competition and business performance. However, much of the existing literal works (Kiama, Kagiri, 2016; Carol et al., 2015; Gültekin et al., 2014) have adopted Porter five forces and grounded theory in their analysis. This study while recognizing Porters five forces, focuses on non-price differentiation business competitive strategies namely product differentiation, service differentiation and physical differentiation. Further, most literal works studying business competitiveness strategies have been foreign, thus by conducting this study in the brewery sector in Cameroon, this study fills an existing gap.

Study conceptual framework. Based on the reviewed literal works, this study developed a conceptual framework illustrating the dependent and independent variables (see Figure). The dependent variable is business performance. The independent variables included: (1) product differentiation viewed from the angles of product quality, product assortment and products position; (2) service differentiation captured through transport service provided, advisement and promotion, rapidity in handling complaints/inquiries and (3) physical differentiation proxied by location, customer convenience and layout.

Eliminating price based differentiation and considering the high saturation of the Bamenda market with brewery products from different firms, this study avers that product differentiation, service differentiation and physical differentiation influences business performance of Les Brasseries Du Cameroun, Bamenda. Thus while acknowledging the likely interplay between the independent variables, this study seeks to determine separately the effects each of the independent variables on business performance. Actual/perceived cumulative value judgment by customer is integrated as the mediating factor in the relationship between the independent variables and the dependent variable business performance. 


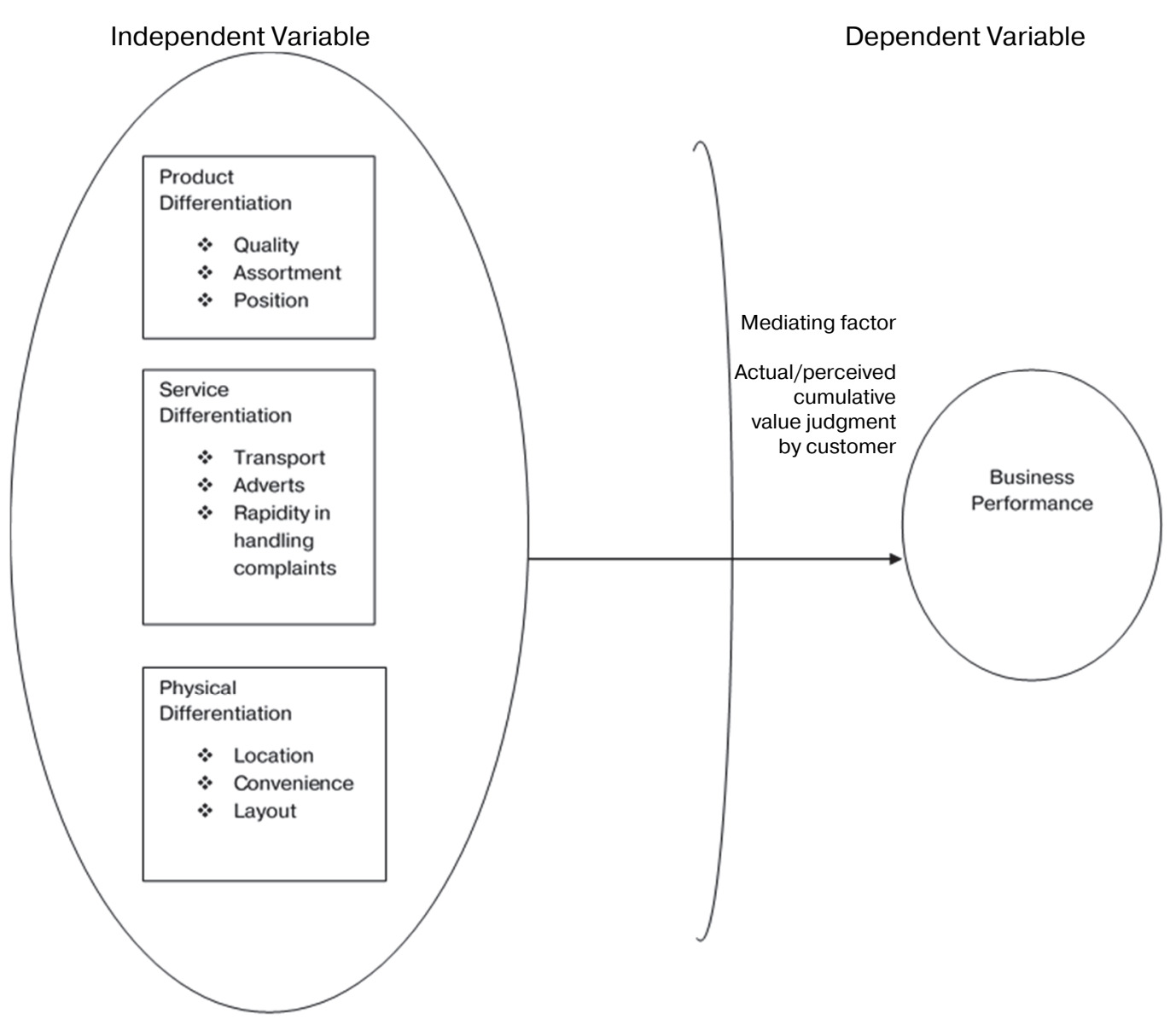

Figure. Conceptual framework of the study

Source: authors' conceptualization.

\section{Methodology}

As aim, this study examines differentiation as a business competitiveness strategy to improve business performance in Les Brasseries Du Cameroun Bamenda. In this respect, the case study research design employing both qualitative and quantitative techniques was adopted to assess the hypothetical relationships stated. From a list of registered business operators dealing in Les Brasseries Du Cameroun products as well as other brewery products, a purposive sample of 200 participants was identified and utilized in this study. Criteria used in selecting the study participants included readiness to participate, their bars must have had sufficient drinking space, they must have fulfilled requirements of operating bars notably availability of rest rooms as well as must have been operational for at least 5 years. Out of the 200 purposefully selected sample population to which questionnaires were given, 130 participants completely filled their questionnaires as well as participated in interviews making the retained and utilized study sample to be 130 participants. With the use of a questionnaire developed with respect to (Likert, 1932) sufficient quantitative data was collected. Through interviews, qualitative data was collected through capturing the opinions of management staff at Les Brasseries Du Cameroun Bamenda as well as managers and staff at retail outlets/bars. 
Through pre-testing of the questionnaire on a sample of 20 , the summation of squared difference was 16 ; that is $\sum d^{2}=16$. The reliability coefficient of the questionnaire was then estimated as follows:

$$
\begin{aligned}
& \text { Reliability Coefficient }(\mathrm{RC})=1-\frac{6 \sum d 2}{n(n 2-1)}, \\
& \qquad \begin{array}{c}
\mathrm{RC}=1-\frac{6(16)}{20(130-1)}, \\
\mathrm{RC}=0.963 .
\end{array}
\end{aligned}
$$

Given that the RC value was between 0.5 and 0.99 , the data collection questionnaire was judged reliable. Again, by employing member checking and the test-retest method, data validity and reliability were further ascertained.

Data collection paid attention to the main study variables with the dependent variable business competitiveness and performance captured through market share. The independent variable differentiation was non price differentiation variables captured through product differentiation (proxied by product quality, product assortment and products position), Physical differentiation (proxied by location, customer convenience and layout) and service differentiation (transport service, advisement and promotion, rapidity in handling complaints/inquiries).

The Pearson's correlation coefficient was the test statistical technique employed to investigate the stated hypothetical relationships that guided the operationalization of the study. It is worth mentioning that Pearson's correlation coefficient provides a measure of strength and direction of the existing relationship varying from -1 to +1 . Positive values indicate that variables are positive correlated and negative values indicate that variables are negatively correlated.

\section{Results}

Products of Les Brasseries Du Cameroun. Data collected from the field revealed that the image of Les Brasseries Du Cameroun is reflected by their products. According to staff at Les Brasseries Du Cameroun, the company has design its products to meet the needs of its customers. In this light, the study uncovered that Les Brasseries is the leading brewery company in Cameroon, with its products grouped into three categories: beer, soft drinks, sirops and alcohol mix.

Further, through document review and observations, the study uncovered that Les Brasseries Du Cameroun produces 19 different drinks namely: beer products - Castel Milk, Castle Beer, “33” Export, Mutzig Beaufort, Beaufort Light; soft drinks - Soda water, Top Orange, Top Anana, Top Grenadine, Top Pamplemousse, Top Tonic, Top Citron, Coca Cola, Djino Cocktail; alcoholic beverages Booster Gin Tonic, Booster Cider, Booster Whisky Cola and Beaufort Tango. This high assortment was observed to be significantly affecting positively on performance and competitiveness of Les Brasseries Du Cameroon as it helps the company meet the needs of a high variety of customers.

It is worth mentioning that Les Brasseries Du Cameroun has two other product categories which it does not produce, thus operating mainly as a distribution partner. These products are mineral water (Source Tangui) and wine namely Vin de Table, Vin Rouge, Vin Rose, Vin de la Vallee du Rhone, Vin de Beaujoiaise and Vin de Bordeaux. 
Hypothesis testing - correlation analysis. The hypothetical relationship guiding the operationalization of this study examined differentiation as the independent variable and dependent variable business performance captured through market share. To ensure a detail investigation, the independent variable was segmented and treated separately resulting in the development of three hypotheses tested in this study as seen below.

Hypothesis 1. Product differentiation has no significant effect on the business performance of Les Brasseries Du Cameroun Bamenda.

Production differentiation was one of the isolated differentiation aspects studied to ascertain the nature of the relationship existing between it and business performance at Les Brasseries Du Cameroun, Bamenda. To this respect, product differentiation was viewed in terms of product quality, product assortment and products position. Correlation analysis performed resulted in the Table 1.

Table 1

Correlation analysis - product differentiation

\begin{tabular}{clcc}
\hline & & $\begin{array}{c}\text { Product } \\
\text { differentiation }\end{array}$ & $\begin{array}{c}\text { Business } \\
\text { performance }\end{array}$ \\
\hline $\begin{array}{c}\text { Product } \\
\text { differentiation }\end{array}$ & Pearson correlation & 1 & $.804^{\star}$ \\
& Sig. (2-tailed) & - & 0.01 \\
& $\mathrm{~N}$ & 130 & 130 \\
\hline Business & Pearson correlation & $.804^{\star}$ & 1 \\
performance & Sig. (2-tailed) & 0.01 & - \\
& $\mathrm{N}$ & 130 & 130 \\
\hline
\end{tabular}

Note. ${ }^{*}$ - correlation significance is measured at 0.01 level (2-tailed).

Source: based on authors' calculations.

The results showed that there is a strong positive relationship between product differentiation and business performance $\left(\mathrm{PCC}=.804^{* *}, p<0.01\right)$, significant at $1 \%$ level. The results imply that the high assortment coupled with quality, have significantly contributed to the high business performance being recorded by Les Brasseries Du Cameroun in Bamenda. This is true for high product assortment, the needs of a large variety of customers are met. Hence through satisfying customer needs business performance is guaranteed. Given the results, it can thus be argued that if Les Brasseries Du Cameroun should continuously maintain and improve on product differentiation, high business performance will always be achieved. On the basis of the correlation results, the null hypothesis which states that product differentiation has no effect on the business performance of Les Brasseries Du Cameroun Bamenda is rejected in favour of the hypothesis which states that product differentiation has a significant effect on the business performance of Les Brasseries Du Cameroun Bamenda.

Hypothesis 2. Service differentiation has a significant effect on the business performance of Les Brasseries Du Cameroun.

Service differentiation was also isolated and examined as an individual variable influencing either positively or negatively on business performance at Les Brasseries Du Cameroun Bamenda. Service differentiation was captured by asking questions in aspects of transport service provided, advisement and promotion, rapidity 
in handling complaints/inquiries. Data generated was tested using the correlation analysis and presented as seen in Table 2 .

Correlation analysis - service differentiation

\begin{tabular}{clcc}
\hline & & $\begin{array}{c}\text { Service } \\
\text { differentiation }\end{array}$ & $\begin{array}{c}\text { Business } \\
\text { performance }\end{array}$ \\
\hline $\begin{array}{c}\text { Service } \\
\text { differentiation }\end{array}$ & Pearson correlation & 1 & $.575^{\star}$ \\
& Sig. (2-tailed) & - & 0.01 \\
& $\mathrm{~N}$ & 130 & 130 \\
\hline $\begin{array}{c}\text { Business } \\
\text { performance }\end{array}$ & Pearson correlation & $.575^{\star}$ & 1 \\
& Sig. (2-tailed) & 0.01 & - \\
\hline
\end{tabular}

Note. ${ }^{*}$ - correlation significance is measured at 0.01 level (2-tailed).

Source: based on authors' calculations.

The results showed that there is a moderate positive relationship between service differentiation and business performance with a coefficient of ( $\mathrm{PCC}=.575$, $p<0.01$ ) at an alpha level of $1 \%$, implying that business performance can also be influenced by the way businesses differentiate their services. Since results suggest the existence of a positive and significant relationship, the hypothesis is accepted that Service differentiation has a significant effect on business performance of Les Brasseries Du Cameroun, Bamenda. Validly, through providing distribution services in town, attaining to complaints/inquiries, more quality assorted drinks are available in the market at the right place and at the right time, thus ensuring that customer needs are satisfied as at when needed, as such translating to better business performance for the enterprise.

Hypothesis 3. Physical differentiation has no significant effect on the business performance of Les Brasseries Du Cameroun.

Correlation analysis - physical differentiation

\begin{tabular}{clcc}
\hline & Physical & $\begin{array}{c}\text { Business } \\
\text { performance }\end{array}$ \\
\hline $\begin{array}{c}\text { Physical } \\
\text { differentiation }\end{array}$ & Pearson Correlation & 1 & $.264^{\star}$ \\
& Sig. (2-tailed) & - & 0.01 \\
& $\mathrm{~N}$ & 130 & 130 \\
\hline $\begin{array}{c}\text { Business } \\
\text { performance }\end{array}$ & Pearson Correlation & .264 & 1 \\
& Sig. (2-tailed) & 0.01 & - \\
\hline
\end{tabular}

Note. ${ }^{*}$ - correlation significance is measured at 0.01 level (2-tailed).

Source: based on authors' calculations.

To test hypothesis 3, physical differentiation was captured through the use of proxies namely location, customer convenience and layout. With the use of the Pearson correlation analysis, the collected data was revealed the nature of the existing relationship as seen in Table 3 .

From results in the table above, there is an indication of a weak positive relationship between physical differentiation and business performance with a Pear- 
son correlation coefficient of $(\mathrm{PCC}=.264, p<0.01)$. By implication, it can thus be argued that physical differentiation has a positive effect which is not very significant on the business performance of Les Brasseries Du Cameroun Bamenda hence accepting the stated hypothesis that: physical differentiation has no significant effect on the business performance of Les Brasseries Du Cameroun Bamenda. Apparently, this finding can be attributed to the fact that in Bamenda breweries products including those of Les Brasseries Du Cameroun are available at very close proximity to customers. Even in residential areas, bars are available to satisfy customer needs at short notice. Further, drinks are also sold in provision shops. Thus because the high competition in the brewery industry in Bamenda has made bars to be located everywhere, the variable physical differentiation seems not to be a key influencing factor given the local reality.

\section{Discussion}

The study established that Les Brasseries Du Cameroun is a leading player in the brewery industry in Cameroun. Through employing differentiation as a business competitive strategy, business performance was observed to be significantly impacted. The study uncovered that product differentiation strategy has created more value and significantly affected positively on Les Brasseries Du Cameroun Bamenda. Thus even with the high competition and the growing saturation of the Bamenda Market with brewery products from neighbouring Nigeria as well as other national breweries, Les Brasseries continue to enjoy market dominance thanks to its high product assortment and quality level. These findings are similar to those of Pearce and Robinson (2005), Grant (2010), Carpenter and Marguerite (2006), Baraza (2017) and Thiane (2018) who argued that through unique product features, higher quality products and assortment, firms are able to provide superior value to customers. Further, as observed, the high product assortment increased the customer base, satisfying a wide range of heterogeneous customers and thus gaining market share. Scholarly works uphold similar finding (Baraza, 2017; Thiane, 2018). It is worth mentioning here that study participants indicated that the quality of brewery products from neighbouring Nigeria was poor when compared with Les Brasseries Du Cameroun Products.

Further, findings suggested that service differentiation through transport service provided, advisement and promotion, rapidity in handling complaints/inquiries resulted in high reliability and satisfaction on licensed wholesalers and retailers. This apparently is responsibility for the observed nature of high availability of all Les Brasseries Du Cameroun products in all retail and wholesale centers visited. Scholarly works of King (2005), Schneider and Bowen (1995), Thompson and Martin (2005) provide similar findings upholding that service differentiation brings about high customer responsiveness which brings value to customers. It is worth mentioning here that during data collection, some bars visited had no Guinness Cameroun products. Given the efficiency of service differentiation, failure costs were noted to be significantly low thus contributing to the performance of the company.

Finally, as concerns physical differentiation, the study found that its effect on business performance of Les Brasseries Du Cameroun Bamenda though posi- 
tive was weak. This could be attributed to the high availability of drinking joins at close proximity in both residential and non-residential areas. It is worth noting that bars are located in every street and every corner of Bamenda. Further, retail provision shops were also observed to be selling brewery products. Apparently, the high density of bars might have made the effect of physical differentiation to be weak contrasting the viewpoint of (Galliers, 2006) that physical differentiation notably through location positioning is a key business performance factor utilized by enterprises in highly competitive markets

\section{Conclusion}

This study concludes that the use of differentiation as a business competitiveness strategy for improving business performance is impacting positively on the performance of Les Brasseries Du Cameroun Bamenda. This implies that capitalizing on product differentiation which ensures quality will result in greater market share for Les Brasseries Du Cameroun Bamenda. Summarily, based on the correlation coefficients, it can thus be stated that with reference to differentiation and business performance of Les Brasseries Du Cameroun, Bamenda, the contributions of the differentiation variables examined can be classified with product differentiation $\left(\mathrm{PCC}=.804^{* *}, p<0.01\right)$ as the most influencing, followed by service differentiation $(\mathrm{PCC}=.575, p<0.01)$ and then physical differentiation $(\mathrm{PCC}=.264$, $p<0.01)$ the least. Several studies have upheld similar findings in varied industries across the world. On this basis, the study thus provides practical advice that management should continue to maintain and uphold product differentiation variable factors like quality and assortment. This will help the enterprise to ensure high loyalty. Further, management needs to step-up service differentiation activities.

Surely, this study had some limitations. Worthy of note include the exclusion of price base differentiation. Also, the COVID-19 pandemic limited the extent of discussions with study participants. More limiting was the sample size of 130. This may appear limiting due to the high density of bars and the number of staff operating in the brewery sector in Bamenda. Despite these limitations, note should be taken that the results apparently are representative of the picture in Bamenda.

For future research, the study recommends a comparative study be carried out to see where the different brewery firms are performing best when compared to others. Also, another study may be conducted to identify the relative contributions of the individual drinks in the Les Brasseries Du Cameroun assortment to organizational performance. This may inform management to know which drinks to pay more attention to. Again, a similar study may be conducted in other industries notably the Banking and Telecoms in Bamenda.

Acknowledgements. Gratitude goes to staff at Les Brasseries Du Cameroun Bamenda as well as managers and staff of retail outlets for their time spent discussing/ answering the study questionnaire.

Conflicts of interest. The authors declare no conflict of interest. 


\section{References}

Baraza, D. (2017). Effects of Competitive Strategies on Performance of Manufacturing Firms in Kenya. A Case Study of East Africa Breweries Limited. Master Research Project. School of Business, The Catholic University Eastern Africa.

Carol, Y.Z., Federico, G., \& Thomas, M.B. (2015). Competitiveness in a Saturated Market. A Case Study of the Scottish Craft Beer Industry. International Journal of Business and Social Science, 6(8), 28-46.

Carpenter, J., \& Marguerite, M. (2006). Consumer demographics, store attributes, and retail format choice in the US grocery market. International Journal of Retail and Distribution Management, 34(6), 434-452.

Chamberlin, E. (1965). A Cognitive Model of the Antecedents and Consequences of Satisfaction Decisions. Journal of Marketing Research, (11), 460-469.

Galliers, I. (2006). Performance impacts of strategic orientations: Evidence from Turkish manufacturing firms. Journal of American Academy of Business, 6(1), 68-72.

Grant, R.M. (2010). Contemporary Strategy Analysis. $7^{\text {th }}$ ed. UK, John Wiley \& Sons Ltd.

Gültekin, A., Fatih, S., Asli, M., \& Çağlar, P. (2014). Industry forces, competitive and functional strategies and organizational performance: Evidence from restaurants in Istanbul, Turkey. Elsevier Procedia - Social and Behavioral Sciences, 150, 300-309.

Harris, L., \& Ogbona, E. (2001). Competitive advantage in the UK food retailing sector: Past, present and future. Journal of Retailing and Consumer Services, (8), 157-173.

Kiama, P., \& Kagiri, A. (2016). Effects of Product Differentiation Strategies on Organizational Competitiveness: A Case of EABL, Kenya. European Journal of Business and Strategic Management, 1(1), 117-133.

King, J. (2005). The Top 10 Reasons Businesses Succeed. Journal of Business Strategies, (28), 9-12.

Likert, R. (1932). A Technique for the Measurement of Attitudes. Archives of Psychology, (140), 1-55.

Lilien, G., \& Kotler, P. (1983). Marketing Decision Making: A Model-Building Approach. New York, Harper \& Row Publishers.

Makadok, R., \& Ross, D.G. (2013). Taking Industry Structuring Seriously: A Strategic Perspective on Product Differentiation. Strategic Management Journal, (34), 509-532.

Obitz, C. (2009). Supermarket Differentiation in the UK: A Theoretical and Empirical Investigation. Diplomica Obitz Gmbh.

Pearce, J., \& Robinson, R. (2005). Strategic Management: Formulation Implementation and Control. $9^{\text {th }}$ ed. New York, Tata McGraw Hill.

Porter, M. (1985). Competitive Advantage: Creating and Sustaining Superior Performance. New York, Free Press.

Schneider, B., \& Bowen, D. (1995). Winning the Service Game. Cambridge, MA, Harvard Business School Press.

Sigler, K. (2010). The U.S. Retail Industry: Are CEOs Paid for Performance? International Review of Business and Social Sciences, 1(4), 33-39.

Thiane, I. (2018). Strategies Employed by Keroche Breweries Ltd to gain Competitive Advantage. Masters Research Project. School of Business, University of Nairobi.

Thompson, A., \& Strickland, A.J. (2007). Crafting and Executing Strategy: The Quest for Competitive Advantage: Concepts and Cases. New York, McGraw Hill.

Thompson, J., \& Martin, F. (2005). Short Term Impact of Differentiation on Organizations Profitability: A Comparative Study Between Convenience and Shopping Goods. International Business and Management, 7(5), 247-255.

\section{Article history:}

Received: 30 June 2020

Revised: 25 July 2020

Accepted: 23 August 2020 


\title{
For citation:
}

Shille, P.N., \& Enow, P. (2020). Differentiation as a business competitiveness strategy in the brewery industry in Cameroon: An analysis of Les Brasseries du Cameroun Bamenda. RUDN Journal of Economics, 28(4), 668-680. http://dx.doi.org/10.22363/2313-2329-202028-4-668-680

\section{Bio notes:}

Peter Ngek Shille, assistant lecturer of the Department of Agribusiness Technology of the College of Technology of the University of Bamenda Cameroon. E-mail: spngek@yahoo.co.uk

Peter Enow, Higher Technical Teacher Training College of the University of Bamenda Cameroon. E-mail: epamelangwi@gmail.com

\section{Дифференциация как фактор конкурентоспособности бизнеса в пивоваренной отрасли Камеруна: анализ Les Brasseries du Cameroun Bamenda}

\author{
П.Н. Шилли, П. Иноу \\ Университет Баменды \\ Республика Камерун, Северо-Западный регион, Бамбили, n/я 39
}

\begin{abstract}
Аннотация. В представленном исследовании на примере Les Brasseries Du Cameroun Bamenda рассматривается дифференциация как стратегия повышения конкурентоспособности и эффективности бизнеса в пивоваренной отрасли с использованием качественных и количественных методов для оценки заявленных гипотетических взаимосвязей. Для сбора данных использовались анкетирование и интервьюирование; специально отобранная выборка состояла из 130 участников - управленческий персонал Les Brasseries Du Cameroun Bamenda, а также менеджеры и сотрудники торговых точек/баров в Баменде. Результаты, полученные с использованием коэффициента корреляции Пирсона в качестве аналитического метода, показали, что существует сильная положительная связь между дифференциацией продуктов и производительностью бизнеса (РСC $=0,804 * *, p<0,01)$, умеренная положительная связь между дифференциацией услуг и производительностью бизнеса $\left(\mathrm{PCC}=0,575^{* *}, p<0,01\right)$ и слабая положительная связь между физической дифференциацией и производительностью бизнеса $(\mathrm{PCC}=0,264 * *, p<0,01)$. Таким образом, можно заключить, что руководству следует продолжать поддерживать переменные факторы дифференциации продуктов, такие как качество и ассортимент.
\end{abstract}

Ключевые слова: дифференциация услуг, эффективность бизнеса, пивоваренная промышленность

Благодарности. Благодарим персонал Les Brasseries Du Cameroun Bamenda, а также менеджеров и сотрудников торговых точек за время, потраченное на обсуждение и заполнение анкеты исследования.

Конфликт интересов. Авторы заявляют об отсутствии конфликта интересов. 


\section{История статьи:}

Дата поступления в редакцию: 30 июня 2020 г.

Дата проверки: 25 июля 2020 г.

Дата принятия к печати: 23 августа 2020 г.

\section{Для цитирования:}

Shille P.N., Enow P. Differentiation as a business competitiveness strategy in the brewery industry in Cameroon: an analysis of Les Brasseries du Cameroun Bamenda // Вестник Российского университета дружбы народов. Серия: Экономика. 2020. Т. 28. № 4. C. 668-680. http://dx.doi.org/10.22363/2313-2329-2020-28-4-668-680

\section{Сведения об авторах:}

Шилли Петер Нгек, ассистент преподавателя кафедры технологии агробизнеса Технологического колледжа Университета Баменды. E-mail: spngek@yahoo.co.uk

Иноу Петер, Высший технический педагогический колледж Университета Баменды. E-mail: epamelangwi@gmail.com 